\title{
Germination Kinetics in Two Acacia karroo Hayne Ecotypes under Salinity Conditions
}

\author{
Abdenour Kheloufi*, Abdelmalek Chorfi, Lahouaria-Mounia Mansouri \\ Department of Ecology and Environment, Faculty of Natural and Life Sciences, University of Batna, Batna, Algeria \\ Email: *abdenour.kheloufi@yahoo.fr
}

How to cite this paper: Kheloufi, A., Chorfi, A. and Mansouri, L.-M. (2017) Germination Kinetics in Two Acacia karroo Hayne Ecotypes under Salinity Conditions. Open Access Library Journal, 4: e3319.

http://dx.doi.org/10.4236/oalib.1103319

Received: December 20, 2016

Accepted: January 9, 2017

Published: January 12, 2017

Copyright (c) 2017 by authors and Open Access Library Inc.

This work is licensed under the Creative Commons Attribution International License (CC BY 4.0).

http://creativecommons.org/licenses/by/4.0/

\begin{abstract}
Acacia karroo Hayne is the most important woody invader of grassland in South Africa, and is one of the fastest-growing acacias, and produces highdensity wood. This study aims to compare the germinative behaviour of $A$. karroo seeds collected from two ecotypes geographically and climatically different (Coastal and Steppic area) in salt stress. The seeds were exposed to saline stress conditions by increasing concentrations of sodium chloride $(\mathrm{NaCl})$ varying from 0 to $50,100,150,200,250,300,400$ and $600 \mathrm{mM}$. Germination was estimated by the daily rates and the final germinated seed rate during a period of 21 days in Petri dishes at $25^{\circ} \mathrm{C}$ ( 5 replicates of 20 seeds). The emergence of seedlings was appreciated by their overall length. The results revealed the existence of a significant variation $(p<0.001)$ between the two seed sources. Indeed, those collected from an arid ecotype were most tolerant at higher sodium chloride concentrations. The response to salinity stress varied in time with $\mathrm{NaCl}$ concentration and seeds origin which could be attributed to intraspecific variations resulting from the natural selection of the same species. Under $400 \mathrm{mM}$ of $\mathrm{NaCl}, 20 \%$ of germination was obtained from the coastal seeds against $66 \%$ from the steppic seeds. The repeated measures analysis of variance also revealed a significant effect of factors "Concentrations of $\mathrm{NaCl}$, ecotypes, time of germination and their correlation" on the kinetics of germination.
\end{abstract}

\section{Subject Areas}

Ecology, Plant Science, Soil Science

\section{Keywords}

Acacia Trees, Seed, Salinization, Tolerance, Forestry

\section{Introduction}

In the world, lands salinization progresses and reaches a fifth of the irrigated 
grounds. Indeed, much of irrigated grounds are threatened by salinization, an accumulation of salts in the soils which decreases plant yields and can deteriorate the agricultural lands in an irrevocable way [1]. Moreover, recurring drought and increasing anthropization led to a strong degradation of ecological systems and to salinization [2]. Arid ecosystems are characterized by a specific climate with a long season of dryness (from 8 to 10 months) and with an intense evapotranspiration [3]. Otherwise, the climatic changes become increasingly constrained for the plant growth and development [4]. Algeria belongs to the Mediterranean countries where drought leads obviously to the process of salinization [5]. These two natural constraints of drought and salinity contribute to deforestation which acts negatively in biodiversity and ecosystem stability.

As much of forest trees, Acacia trees are frequently used in reforestation programs [6] [7] and in agro-sylvo-pastoral adjustment systems for arid and semiarid regions. They are highly drought tolerant and are well-adapted to the poor soils of their environment [8] [9] [10]. These species are also well adapted to the degraded area and contrasted climatic conditions [11] [12] [13]. These properties are especially related to their capacities of symbiosis with beneficial microorganisms of the ground: rhizobium and mycorrhizae [14]. Acacia karroo is one of the fastest-growing acacias and produces high-density wood $\left(800-890 \mathrm{~kg} / \mathrm{m}^{3}\right)$ and is very useful for the best honey production. It is named Sweet thorn and is a small to medium-sized tree, usually $4-8 \mathrm{~m}$ tall, but specimens up to $17 \mathrm{~m}$ tall have been found [15].

The fundamental importance of germination physiology to agriculture and horticulture is so obvious that it needs hardly to be stated, because almost all of our reliance on plants depends ultimately on the germinability of their seeds. The stage of germination is often limited by several environmental factors such as temperature, salinity, light, soil moisture, oxygen concentration and $\mathrm{pH}$ [16]. Thus, seed germination has a great importance for natural or artificial regeneration. Moreover, the intraspecific variations of tolerance to salinity can be remarkable [17]. In this investigation, the effects of saline stress were studied for two ecotypes of Acacia karroo Hayne seeds by using sodium chloride ( $\mathrm{NaCl})$ solutions with concentrations varying from 0 (Control) to $600 \mathrm{mM}$. The aim is to evaluate the influence of saline stress on the germination and the emergence of the vegetative apparatus and to determine if there is a significant intraspecific variation for tolerance to salinity between seeds of different bioclimatic zones (Coastal and Steppic).

\section{Materials and Methods}

\subsection{Plant Material}

We used seeds of Acacia karroo, one batch was collected from Msila forest, a coastal forest in the west of Oran (Algeria), area with Mediterranean climate of the North-West of Algeria (35 38'35.3"N, $\left.0^{\circ} 51^{\prime} 33.2^{\prime \prime} \mathrm{W}\right)$. The second batch was sampled from the forest of Sen El Bae, area of Djelfa $\left(34^{\circ} 40^{\prime} 00.3^{\prime \prime} \mathrm{N}, 3^{\circ} 09^{\prime} 18.8^{\prime \prime} \mathrm{E}\right)$, a steppic area localized in the south-west of Oran (Algeria) and characterized 
with an arid climate. Plants were authenticated by Algerian Forest Research Institute. The mature pods were collected on 10 different trees in 2015. We have extracted the seeds from the dried pods by carefully crushing or breaking open the seedpods. Crushed debris was then separated from the seeds by sifting everything through a fine mesh screen. The flotation was also used to sort out seeds. The test of flotation aims at eliminating empty seeds, broken and insect-damaged. The clean seeds, of a weight of (21 to 23 grams/1000 seeds), were then deposited on the filter paper to dry. Once dried, they are stored in glass container $4^{\circ} \mathrm{C}$, to simulate the vernalization condition for 2 months-period, waiting their manipulation in 2016.

\subsection{Germination Conditions and Salinity Treatments}

Factorial combinations of two sources of A.karroo and nine levels were salinity test treatments. Salinity levels of 0,50,100,150,200,250,300,400, $600 \mathrm{mM}$ (millimolar) were created using sodium chloride $(\mathrm{NaCl})$. First of all, collected seeds were cleaned then placed in boiled distilled water for three minutes, as a well-known pre-germination treatment for most Acacia seeds [19].

Twenty seeds per dish were used for each treatment. Seeds were germinated in $10 \mathrm{~cm}$ Petri dishes with Whatman filter papers $\mathrm{N}^{\circ} 1$ humidified with the appropriate solution or distilled water for $0 \mathrm{mM}$ (Control) of $\mathrm{NaCl}$ concentration. Seeds were incubated under continuous dark at $25^{\circ} \mathrm{C} \pm 1^{\circ} \mathrm{C}$ (Celsius) in controlled temperature room. The papers were changed with the same treatment each 3 days to prevent salt accumulation [18]. The seeds were moistened with the appropriate solutions of $\mathrm{NaCl}$ and kept wet throughout the experiment. The germination criterion was taken into account when radicle had pierced the tegument with $2 \mathrm{~mm}$ (millimeter) in length [20].

\subsection{Studied Parameters}

The studied parameters during this work were:

Final germination percentage (FGP): this parameter constitutes the best identification means of salt concentration which presents the physiological limit of germination. It is expressed by the report/ratio numbers seeds germinated on a total number of seeds [21].

Kinetics of germination: for better apprehending the physiological significance of germination behavior, the number of germinated seeds was counted every 3 days until the $21^{\text {st }}$ day of the experiment.

Mean Daily Germination (MDG): MDG is the percentage of final germination /number of days to final germination [22].

Lengths of the seedlings (LS): the length of seedlings in centimeter $(\mathrm{cm})$ was measured using a cotton yarn because of the seedling curves in Petri dishes after 21 days of sowing.

\subsection{Statistical Analysis}

The experiment was made as a completely randomized design with five repli- 
cates of twenty seeds $(n=5)$. The variances from each Petri dish comfort the data to be reliable. The data were statistically treated by Fisher's analysis of variance (ANOVA). The Generalized Linear Model (GLM) was used in the kinetics of germination (Repeated Measures Analysis of Variance). The means values of provenances, after sodium chloride treatments and their interactions were compared by the Duncan's Multiple Range Test at $p \leq 0.05$ using SAS software version 9.0 (SAS 2002).

\section{Results}

The results of a two-way-ANOVA clearly indicate that the treatments operated by the various concentrations of sodium chloride exerted a very highly significant effect on the germinative capacity and seedlings length growth (Table 1 and Table 2). Overall, this germination rate decreased when the saline stress increased. However, a clear difference was observed between the two sources of seeds where the steppic seeds seemed to present a better behavior with respect to increasing in treatment levels. In addition, no germination appeared up to 600 $\mathrm{mM}$ of $\mathrm{NaCl}$ for both ecotypes (Table 2).

Table 1. Effect of $\mathrm{NaCl}(\mathrm{mM})$ on different germination parameters.

\begin{tabular}{|c|c|c|c|c|}
\hline Ecotypes & $\mathrm{NaCl}(\mathrm{mM})$ & FGP (\%) & MDG (\%) & $\mathrm{SL}(\mathrm{cm})$ \\
\hline \multirow{9}{*}{$\begin{array}{l}\text { Acacia karroo } \\
\text { (Coastal area) }\end{array}$} & 0 (Control) & $96 \pm 5.47 a$ & $4.57 \pm 0.26 a$ & $11.3 \pm 1.17 \mathrm{a}$ \\
\hline & 50 & $50 \pm 10.00 b$ & $2.38 \pm 0.47 b$ & $6.57 \pm 0.78 b$ \\
\hline & 100 & $46 \pm 13.41 b$ & $2.19 \pm 0.63 b$ & $5.23 \pm 0.59 c$ \\
\hline & 150 & $40 \pm 15.81 \mathrm{cb}$ & $1.90 \pm 0.75 \mathrm{cb}$ & $3.81 \pm 0.36 \mathrm{~d}$ \\
\hline & 200 & $30 \pm 17.32 \mathrm{~cd}$ & $1.42 \pm 0.82 \mathrm{~cd}$ & $2.78 \pm 0.47 \mathrm{e}$ \\
\hline & 250 & $28 \pm 4.47 c d$ & $1.33 \pm 0.21 \mathrm{~cd}$ & $1.3 \pm 0.34 \mathrm{f}$ \\
\hline & 300 & $22 \pm 10.95 d$ & $1.04 \pm 0.52 \mathrm{~d}$ & $1.16 \pm 0.28 f$ \\
\hline & 400 & $20 \pm 15.81 d$ & $0.95 \pm 0.75 \mathrm{~d}$ & $0.88 \pm 0.25 f$ \\
\hline & 600 & $0 \mathrm{e}$ & $0 \mathrm{e}$ & $0 \mathrm{~g}$ \\
\hline \multirow{9}{*}{$\begin{array}{l}\text { Acacia karroo } \\
\text { (Steppic area) }\end{array}$} & 0 (Control) & $100 \pm 0.00 \mathrm{a}$ & $4.76 \pm 0.00 a$ & $12.75 \pm 0.4 a$ \\
\hline & 50 & $100 \pm 0.00 a$ & $4.76 \pm 0.00 \mathrm{a}$ & $12.63 \pm 0.54 \mathrm{ab}$ \\
\hline & 100 & $100 \pm 0,00 a$ & $4.76 \pm 0.00 \mathrm{a}$ & $11.92 \pm 0.79 b$ \\
\hline & 150 & $98 \pm 4.47 \mathrm{a}$ & $4.66 \pm 0.21 \mathrm{a}$ & $9.52 \pm 1.33 c$ \\
\hline & 200 & $96 \pm 5.47 a$ & $4.57 \pm 0.26 a$ & $6.92 \pm 0.96 \mathrm{~d}$ \\
\hline & 250 & $92 \pm 10.95 \mathrm{ab}$ & $4.38 \pm 0.52 \mathrm{ab}$ & $4.07 \pm 0.79 \mathrm{e}$ \\
\hline & 300 & $84 \pm 15.16 b$ & $4 \pm 0.72 b$ & $3.3 \pm 0.71 \mathrm{f}$ \\
\hline & 400 & $66 \pm 8.94 c$ & $3.1 \pm 0.42 c$ & $1.07 \pm 0.67 \mathrm{~g}$ \\
\hline & 600 & $0 \mathrm{~d}$ & $0 \mathrm{~d}$ & $0 \mathrm{~h}$ \\
\hline
\end{tabular}

FGP: final germination percentage; MDG: mean daily germination; SL: seedlings length (SL). Values are means of five replicates of 20 seeds \pm SD for the germination parameters and means of eight replicates \pm SD for the length. Different letters in the same column indicate significant difference at 0.05 , as assessed by Duncan's Multiple Range Tests. 
Table 2. Variance analysis for the traits investigated for the two ecotypes of Acacia karroo Hayne seeds (Coastal and Steppic) in response to salinity stress.

\begin{tabular}{|c|c|c|c|c|c|}
\hline Parameters & Source of Variables & DF & Sum of Squares & Mean Square & F of Fisher \\
\hline \multirow{3}{*}{ FGP } & {$[\mathrm{NaCl}](\mathrm{mM})$} & 8 & 586.2 & 73.27 & $76.24^{\star * \star}$ \\
\hline & Ecotypes & 1 & 453.37 & 453.37 & $471.72^{* * *}$ \\
\hline & {$[\mathrm{NaCl}] \times$ Ecotypes } & 8 & 126.82 & 15.85 & $1649^{* * *}$ \\
\hline \multirow{3}{*}{ MDG } & {$[\mathrm{NaCl}](\mathrm{mM})$} & 8 & 1.32 & 0.16 & $76.23^{* * *}$ \\
\hline & ecotypes & 1 & 1.02 & 1.02 & $471.73^{* * *}$ \\
\hline & {$[\mathrm{NaCl}] \times$ Ecotypes } & 8 & 0.28 & 0.03 & $16.49^{\star * *}$ \\
\hline \multirow{3}{*}{ SL } & {$[\mathrm{NaCl}](\mathrm{mM})$} & 8 & 2233.43 & 279.17 & $613.56^{\star * *}$ \\
\hline & Ecotypes & 1 & 377.65 & 377.65 & $829.97^{* * *}$ \\
\hline & {$[\mathrm{NaCl}] \times$ Ecotypes } & 8 & 204.88 & 25.61 & $56.29^{* * *}$ \\
\hline \multicolumn{6}{|c|}{ Generalized Linear Model (GLM) (Repeated Measures Analysis of Variance) } \\
\hline \multirow{9}{*}{$\begin{array}{l}\text { Kinetics of } \\
\text { Germination }\end{array}$} & & etwee & Subjects Effects & & \\
\hline & {$[\mathrm{NaCl}](\mathrm{mM})$} & 8 & 4403.17 & 550.39 & $104.87^{* * *}$ \\
\hline & Ecotypes & 1 & 2871.46 & 2871.46 & $547.11^{* * *}$ \\
\hline & {$[\mathrm{NaCl}] \times$ Ecotypes } & 8 & 704.66 & 88.08 & $16.78^{\star * *}$ \\
\hline & \multicolumn{5}{|c|}{ Within Subjects Effects } \\
\hline & Time (days) & 6 & 283.75 & 47.29 & $160.98^{* * *}$ \\
\hline & Time $\times[\mathrm{NaCl}]$ & 48 & 242.64 & 5.05 & $17.21^{\star * *}$ \\
\hline & Time $\times$ Ecotypes & 6 & 10.87 & 1.81 & $6.17^{\star * *}$ \\
\hline & Time $\times[\mathrm{NaCl}] \times$ Ecotypes & 48 & 178.9 & 3.71 & $12.63^{\star * *}$ \\
\hline
\end{tabular}

${ }^{*},{ }^{* *},{ }^{* *}$ : significant at $5 \%, 1 \%$ and $0.1 \%$ level, respectively; and ns: not significant. FGP: final germination percentage; MDG: mean daily germination; SL: seedlings length (SL) (cm). DF: degree of freedom.

\subsection{Final Germination Percentage}

Table 1 represents the response of germination to the saline stress for two batches of $A$. karroo seeds collected from two bioclimatically different areas. We clearly observe the clear effect of the seeds origin with regard to salinity tolerance. The treatment effect of $\mathrm{NaCl}$ with its increasing concentrations doesn't have a great influence on the germination of $A$. karroo seeds (Steppic). On the other hand, the effect of $\mathrm{NaCl}$ was distinctly significant for the seeds collected from the coastal area, confirming its salt sensitivity (Table 1 and Table 2). For 0 $\mathrm{mM}$ of $\mathrm{NaCl}$, whatever the origin of the seeds, the maximum rate of germination was equal or very close to $100 \%$ from both provenances. The final rate of germination reflected clearly that the seeds of $A$. karroo (Steppic) are salt tolerant.

\subsection{Kinetics of Germination}

Table 2 indicates that the results of repeated measures analysis of variance were statistically significant $(p<0.001)$ between-subjects effects $(\mathrm{NaCl}$ concentrations $\times$ provenances) and within-subjects effects (time $\times \mathrm{NaCl}$ concentrations $\times$ pro- 
venances). Indeed, the examination of Figure 1, representing the dynamics of the rates of germination according to the increasing $\mathrm{NaCl}$ concentrations illustrated three phases, a first phase of latency, due to imbibition after some time, a second exponential phase showed an acceleration of germination and finally a third phase characterized by a stage indicating a stationary phase of seed germination. In $0 \mathrm{mM}$ of $\mathrm{NaCl}$, the phase of latency and the exponential phase were very short and last only three days before reaching the stationary phase for the steppic seeds. In the same condition; these phases took 12 days for the coastal seeds (Figure 1). In the presence of $\mathrm{NaCl}$, a reduction of the rate and the speed of seed germination were observed in the littoral seeds of A. karroo. Salinity levels affected also $A$. karroo seeds from collected the arid climate, except that their kinetics of germination was maintained at distinct intervals showing a good tolerance to $\mathrm{NaCl}$ (Figure 1).

\subsection{Mean Daily Germination}

For both zones, salinity effect (concentration) resulted in increasing or reducing of germination speed compared to the control. The rate of germination of $A$. karroo (Steppic) was much more significant than that observed for the coastal seeds in saline conditions. Mean daily germination tended to be completely canceled at $600 \mathrm{mM}$ of $\mathrm{NaCl}$ for both studied ecotypes (Table 1).

\subsection{Seedling Emergence}

The effect of $\mathrm{NaCl}$ on seedlings emergence of Acacia karroo was evaluated by measurement of only one morphological characteristic which was the total length of the 21-days old seedlings. The two-way analysis of variance (provenances and $\mathrm{NaCl}$ concentrations), showed a highly significant provenance and

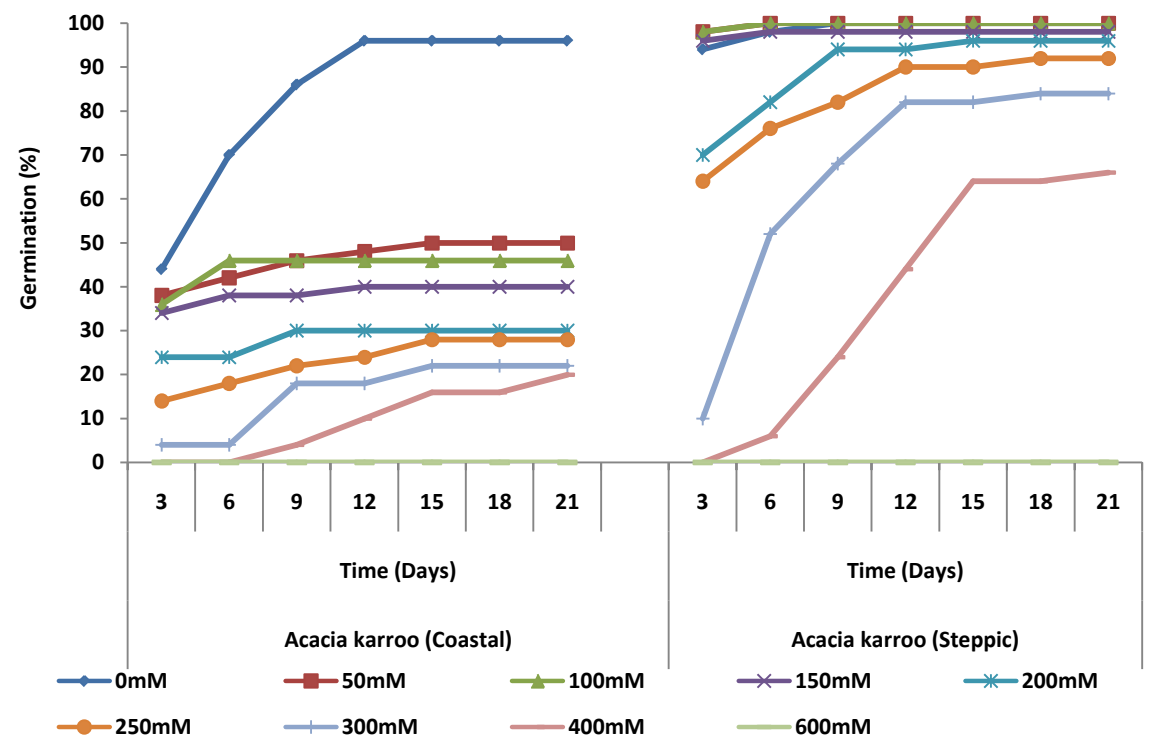

Figure 1. Effects of various $\mathrm{NaCl}$ concentrations (0 to $600 \mathrm{mM}$ ) on the kinetics of germination of two different ecotypes of Acacia karroo Hayne seeds (Coastal and Steppic) over a 21-day period. 
concentration effect $(p<0.001)$ and also for their interaction (provenances $\times$ concentration of $\mathrm{NaCl}$ ) for the parameter: length (Table 2). According to Table 1, we noted that for all used concentrations, the effect of $\mathrm{NaCl}$ on Acacia karroo seeds was different from one area to another and this even under $0 \mathrm{mM}$ where seedlings of $A$. karroo of the arid region showed a growth in length higher than those for the coastal region. The seedlings of $A$. karroo of the steppic source appeared to be the most salt-tolerant even if their growth is reduced by half at the concentrations ranging from 100 to $200 \mathrm{mM}$ of $\mathrm{NaCl}$. The effect of the progressive increase in $\mathrm{NaCl}$ concentration in culture medium resulted in a strong reduction of the seedlings length.

\section{Discussion}

A large number of studies have been carried out on the effects of drought and salinity stress on the germination of forest tree species. Until now, the comparative studies of various species of Acacia under salinity stress were rare. The majority of species and ecotypes showed different sensitivity to the saline stress in regard to seed germination [23] [24] [25]. Few of these studies took into account the provenance selection based on bioclimatic classification. The germination is the first delicate stage for planting the production and the seeds are confronted with a serious problem of soil salinization [26] [27] [28] [29]. [30] has assessed that the saline stress is of paramount importance in determining seed characteristics and germination limitations in arid and semi-arid areas.

According to our results, the seeds of Acacia karroo germinated in the absence and/or in the presence of a low or high concentration of $\mathrm{NaCl}$, are salt-tolerant, but this tolerance differs according to ecotype. For all the studied parameters, the collected seeds from the arid area showed very interesting results. This type of response has been interpreted as indicative of salt-tolerance. Research of [31] and those of [32] have affirmed that the seed germination in saline medium is related to the species. The salt stress of sodium chloride caused a decrease of final percentage of germination. Seed germination was reduced considerably in high salt level $(400 \mathrm{mM})$. Indeed, high salt concentration of a germination medium may induce a reduction and delay in seed germination.

Salinity affects germination in two ways: there can be enough salts in culture medium which reduce the osmotic potential, changing the enzyme activity in the process of hydrolysis of reserves [33]. [34] showed that the osmotic effects result in the inability of seeds to absorb sufficient quantities of water to bring back their critical point of hydration to release the process of germination. However, the toxic effect is related to a cellular accumulation of salts which cause disturbances in enzymes metabolism and respiration. Many studies have shown that the effect of salt on germination could be an inhibitor (toxic) when the concentration is very high, or speed reducer (osmotic) when the concentration is lower [35] [36] [37]. Increased salinity leads to a delay in germination due by the necessary time to seeds to adjust their intern osmotic pressure [38]. [39] has also shown that the aptitude to germinate under drought or salinity conditions does not necessarily reflect the behavior of the adult plants. 
By following the lengths of the plants under salt stress during the treatment periods, it appears there is a general trend for the decrease in the lengths of the seedlings using increasing sodium chloride concentrations for ecotype seeds. The reasons of this reduction can be explained by the inhibition of water uptake, caused by excessive accumulation of ions $\mathrm{Na}^{+}$and $\mathrm{Cl}^{-}$[40]. These weak lengths were also in relation to the delay of seed germination. Under natural conditions, salt dependence and salt tolerance at germination stage are of great interest because successful germination in a wide range of conditions increases the probability of naturalization and soil rehabilitation. Understanding seed characteristics and seedling establishment patterns is essential for the development of effective management strategies for afforestation-reforestation [41].

In this study, it was possible to evaluate and to determine the most salt-tolerant seeds which provided from the steppic ecotype for their use in afforestation and reforestation systems in the arid and semi-arid regions where salinity does not stop progressing. The seeds of this ecotype could be the objective of future selection in order to fix the character of salt-tolerance. Moreover, as the culture is an invasive leguminous tree, it could contribute effectively and quickly to the nitrogen amendment in the degraded grounds and serve as a good conception point to restore the biodiversity.

\section{References}

[1] Qadir, M. (2016) Policy Note: Reversing Salt-Induced Land Degradation Requires Integrated Measures. Water Economics and Policy, 2, 1-8.

https://doi.org/10.1142/S2382624X16710016

[2] Gouaidia, L., Guefaifia, O., Boudoukha, A., Hemila, L.M. and Martin, C. (2012) Évaluation de la salinité des eaux souterraines utilisées en irrigation et risques de dégradation des sols: exemple de la plaine de Meskiana (Nord-Est Algérien). Physio-Géo. Géographie, Physique, et Environnement, 6, 141-160. https://doi.org/10.4000/physio-geo.2632

[3] Parvin, S., Biswas, S., Razzaque, S., Haque, T., Elias, S.M., Tammi, R.S. and Seraj, Z.I. (2015) Salinity and Drought Tolerance Conferred by in Planta Transformation of SNAC1 Transcription Factor into a High-Yielding Rice Variety of Bangladesh. Acta Physiologiae Plantarum, 37, 1-12. https://doi.org/10.1007/s11738-015-1817-8

[4] Liu, Y., Stanturf, J. and Goodrick, S. (2010) Trends in Global Wildfire Potential in a Changing Climate. Forest Ecology and Management, 259, 685-697. https://doi.org/10.1016/j.foreco.2009.09.002

[5] Grace, J., Berninger, F. and Nagy, L. (2002) Impacts of Climate Change on the Tree Line. Annals of Botany-London, 90, 537-544. https://doi.org/10.1093/aob/mcf222

[6] Bencherif, K., Boutekrabt, A., Fontaine, J., Laruelle, F., Dalpè, Y. and Anissa, L.H.S. (2015) Impact of Soil Salinity on Arbuscularmycorrhizal Fungi Biodiversity and Microflora Biomass Associated with Tamarix articulate Vahll Rhizosphere in Arid and Semi-Arid Algerian Areas. Science of the Total Environment, 533, 488-494. https://doi.org/10.1016/j.scitotenv.2015.07.007

[7] Qadir, M. (2016) Policy Note: Reversing Salt-Induced Land Degradation Requires Integrated Measures. Water Economics and Policy, 2, 1-8. https://doi.org/10.1142/S2382624X16710016

[8] Lahdachi, F.Z., Nassiri, L., Ibijbijen, J. and Mokhtari, F. (2015) Aperçu sur les 
acacias spontanés et introduits au Maroc. European Scientific Journal, 11, 88-102.

[9] Padilla, F.M. and Pugnaire, F.I. (2006) The Role of Nurse Plants in the Restoration of Degraded Environments. Frontiers in Ecology and the Environment, 4, 196-202. https://doi.org/10.1890/1540-9295(2006)004[0196:TRONPI]2.0.CO;2

[10] Shah, M. and Hussain, F. (2009). Phytosociological Study of the Vegetation of Hayat Abadpeshawar, Pakistan. Pakistan Journal of Plant Sciences, 15, 1-12.

[11] Bouillet, J.P., Laclau, J.P., de Moraes Gonçalves, J.L., Voigtlaenderb, M., Gavad, J.L., Leitee F.P., Hakamadaf, R., Mareschala, L., Mabialag, A., Tardyh, F., Levillaing, J., Deleportea, P., Eprona, D. and Nouvellona, Y. (2013) Eucalyptus and Acacia Tree Growth over Entire Rotation in Single- and Mixed-Species Plantations across Five Sites in Brazil and Congo. Forest Ecology and Management, 301, 89-101. https://doi.org/10.1016/j.foreco.2012.09.019

[12] Scott, S.J., Jones, R.A. and Williams, W.A. (1984) Review of Data Analysis Methods for Seed Germination. Crop Science, 24, 1192-1199. https://doi.org/10.2135/cropsci1984.0011183X002400060043X

[13] Diouf, D., Samba-Mbaye, R., Lesueur, D., Ba, A.T., Dreyfus, B., De Lajudie, P. and Neyra, M. (2007) Genetic Diversity of Acacia seyal Del. Rhizobial Populations Indigenous to Senegalese Soils in Relation to Salinity and $\mathrm{pH}$ of the Sampling sites. $\mathrm{Mi}$ crobial Ecology, 54, 553-566. https://doi.org/10.1007/s00248-007-9243-0

[14] Rundel, P.W., Dickie, I.A. and Richardson, D.M. (2014) Tree Invasions into Treeless Areas: Mechanisms and Ecosystem Processes. Biological Invasions, 16, 663-675. https://doi.org/10.1007/s10530-013-0614-9

[15] Founoune, H., Duponnois, R. and Bâ, A.M. (2002) Ectomycorrhization of Acacia mangium Willd. and Acacia holosericea, a. Cunn. Ex G. Don in Senegal. Impact on Plant Growth, Populations of Indigenous Symbiotic Microorganisms and Plant Parasitic Nematodes. Journal of Arid Environment, 50, 325-332. https://doi.org/10.1006/jare.2001.0800

[16] Muhammad, A., Odunola, O.A., Gbadegesin, M.A., Adegoke, A.M., Olugbami, J.O. and Uche, N.S. (2015) Modulatory Role of Acacia Honey from North-West Nigeria on Sodium Arsenite-Induced Clastogenicity and Oxidative Stress in Male Wistar Rats. Natural Product Research, 29, 321-326. https://doi.org/10.1080/14786419.2014.940945

[17] Flowers, T.J. (2004) Improving Crop Salt Tolerance. Journal of Experimental Botany, 55, 307-319. https://doi.org/10.1093/jxb/erh003

[18] Akbarimoghaddam, H., Galavi, M., Ghanbari, A. and Panjehkeh, N. (2011) Salinity Effects on Seed Germination and seedling Growth of Bread Wheat Cultivars. Trakia Journal of Sciences, 9, 43-50.

[19] Sweedman, L. and Merritt, D. (2006) Australian Seeds: A Guide to Their Collection, Identification and Biology. CSIRO Publishing, Clayton, $258 \mathrm{p}$.

[20] Egley, G.H. (1978) Germination and Viability of Weed Seeds after 2.5 Years in a 50-Year Buried Seed Study. Weed Science, 26, 230-239.

[21] Côme, D. (1970) Les obstacles à la germination. Monographies de Physiologie Végétale No. 6, Masson, Paris.

[22] Padilla, F.M. and Pugnaire, F.I. (2006) The Role of Nurse Plants in the Restoration of Degraded Environments. Frontiers in Ecology and the Environment, 4, 196-202. https://doi.org/10.1890/1540-9295(2006)004[0196:TRONPI]2.0.CO;2

[23] Everitt, J.H. (1983) Seed Germination Characteristics of Two Woody Legumes (Retama and Twisted acacia) from South Texas. Journal of Range Management, 36, 411-414. https://doi.org/10.2307/3897928 
[24] Tiwari, R.S., Picchioni, G.A., Steiner, R.L., Hughs, S.E., Jones, D.C. and Zhang, J. (2013) Genetic Variation in Salt Tolerance during Seed Germination in a Backcross Inbred Line Population and Advanced Breeding Lines Derived from Upland cotton $\times$ Pima cotton. Crop Science, 53, 1974-1982. https://doi.org/10.2135/cropsci2013.01.0028

[25] Ungar, I.A. (1995) Seed Germination and Seed-Bank Ecology in Halophytes. In: In: Kigel, J. and Galili, G., Eds., Seed Development and Germination, Marcel Dekker, New York, 599-628.

[26] Ayers, A.D. (1952) Seed Germination as Affected by Soil Moisture and Salinity. Agronomy Journal, 44, 82-84.

https://doi.org/10.2134/agronj1952.00021962004400020006x

[27] Balakhnina, T., Bulak, P., Nosalewicz, M., Pietruszewski, S. and Włodarczyk, T. (2015) The Influence of Wheat Triticum aestivum L. Seed Pre-Sowing Treatment with Magnetic Fields on Germination, Seedling Growth, and Antioxidant Potential under Optimal Soil Watering and Flooding. Acta Physiologiae Plantarum, 37, 59. https://doi.org/10.1007/s11738-015-1802-2

[28] Flowers, T.J. (2004) Improving Crop Salt Tolerance. Journal of Experimental Botany, 55, 307-319. https://doi.org/10.1093/jxb/erh003

[29] Redmann, R.E. (1974) Osmotic and Specific Ion Effects on the Germination of Alfalfa. Canadian Journal of Botany, 52, 803-808. https://doi.org/10.1139/b74-104

[30] Ashraf, M. and Orooj, A. (2006) Salt Stress Effects on Growth, Ion Accumulation and Seed Oil Concentration in an Arid Zone Traditional Medicinal Plant Ajwain (Trachyspermum ammi (L.) Sprague). Journal of Arid Environments, 64, 209-220. https://doi.org/10.1016/j.jaridenv.2005.04.015

[31] Lessani, H. and Marschner, H. (1978) Relation between Salt Tolerance and LongDistance Transport of Sodium and Chloride in Various Crop Species. Functional Plant Biology, 5, 27-37. https://doi.org/10.1071/pp9780027

[32] Parida, A.K. and Das, A.B. (2005) Salt Tolerance and Salinity Effects on Plants: A Review. Ecotoxicology and Environmental Safety, 60, 324-349.

https://doi.org/10.1016/j.ecoenv.2004.06.010

[33] Dkhil, B.B. and Denden, M. (2010) Salt Stress Induced Changes in Germination, Sugars, Starch and Enzyme of Carbohydrate Metabolism in Abelmoschus esculentus (L.) Moench Seeds. African Journal of Agricultural Research, 5, 1412-1418.

[34] Rejili, M., Vadel, A.M., Guetet, A., Mahdhi, M., Lachiheb, B., Ferchichi, A. and Mars, M. (2010) Influence of Temperature and Salinity on the Germination of Lotus creticus (L.) from the Arid Land of Tunisia. African Journal of Ecology, 48, 329-337. https://doi.org/10.1111/j.1365-2028.2009.01111.x

[35] Ramoliya, P.J., Patel, H.M. and Pandey, A.N. (2004) Effect of Salinization of Soil on Growth and Macro and Micronutrient Accumulation in Seedlings of Acacia catechu. Annals of Applied Biology, 144, 321-332. https://doi.org/10.1111/j.1744-7348.2004.tb00347.x

[36] Rehman, S., Harris, P.J., Bourne, W.F. and Wilkin, J. (2000) The Relationship between Ions, Vigour and Salinity Tolerance of Acacia Seeds. Plant and Soil, 220, 229233. https://doi.org/10.1023/A:1004701231183

[37] Zhang, H., Zhang, G., Lü, X., Zho, D. and Han, X. (2014) Salt Tolerance during Seed Germination and Early Seedling Stages of 12 Halophytes. Plant and Soil, 388, 229-241. https://doi.org/10.1007/s11104-014-2322-3

[38] Okçu, G., Kaya, M.D. and Atak, M. (2005) Effects of Salt and Drought Stresses on Germination and Seedling Growth of Pea (Pisum sativum L.). Turkish Journal of 
Agriculture and Forestry, 29, 237-242.

[39] Sy, A., Grouzis, M. and Danthu, P. (2001) Seed Germination of Seven Sahelian Legume Species. Journal of Arid Environment, 49, 875-882.

https://doi.org/10.1006/jare.2001.0818

[40] Alencar, N.L., Gadelha C.G., Gallão M.I., Dolder M.A., Prisco J.T. and Gomes-Filho E. (2015) Ultrastructural and Biochemical Changes Induced by Salt Stress in Jatropha curcas Seeds during Germination and Seedling Development. Functional Plant Biology, 42, 865-874. https://doi.org/10.1071/FP15019

[41] Ghars, M.A., Parre, E., Debez, A., Bordenave, M., Richard, L., Leport, L., Bouchereau, A., Savouré, A. and Abdelly, C. (2008) Comparative Salt Tolerance Analysis between Arabidopsis thaliana and Thellungiella halophila, with Special Emphasis on $\mathrm{K}^{+} / \mathrm{Na}^{+}$Selectivity and Proline Accumulation. Journal of Plant Physiology, 165, 588 599. https://doi.org/10.1016/j.jplph.2007.05.014

Submit or recommend next manuscript to OALib Journal and we will provide best service for you:

- Publication frequency: Monthly

- 9 subject areas of science, technology and medicine

- Fair and rigorous peer-review system

- Fast publication process

- Article promotion in various social networking sites (LinkedIn, Facebook, Twitter, etc.)

- Maximum dissemination of your research work

Submit Your Paper Online: Click Here to Submit

Or Contact service@oalib.com 